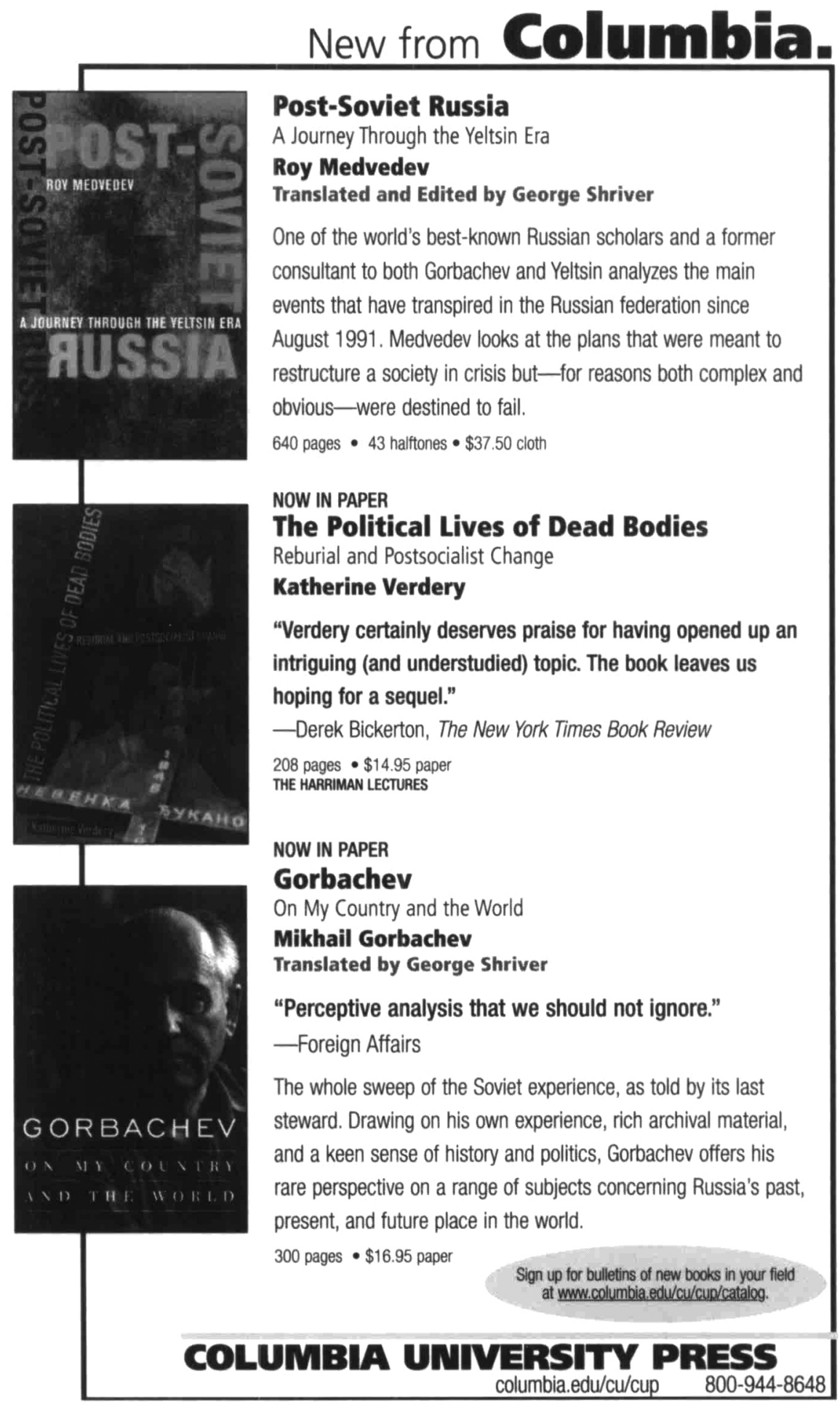




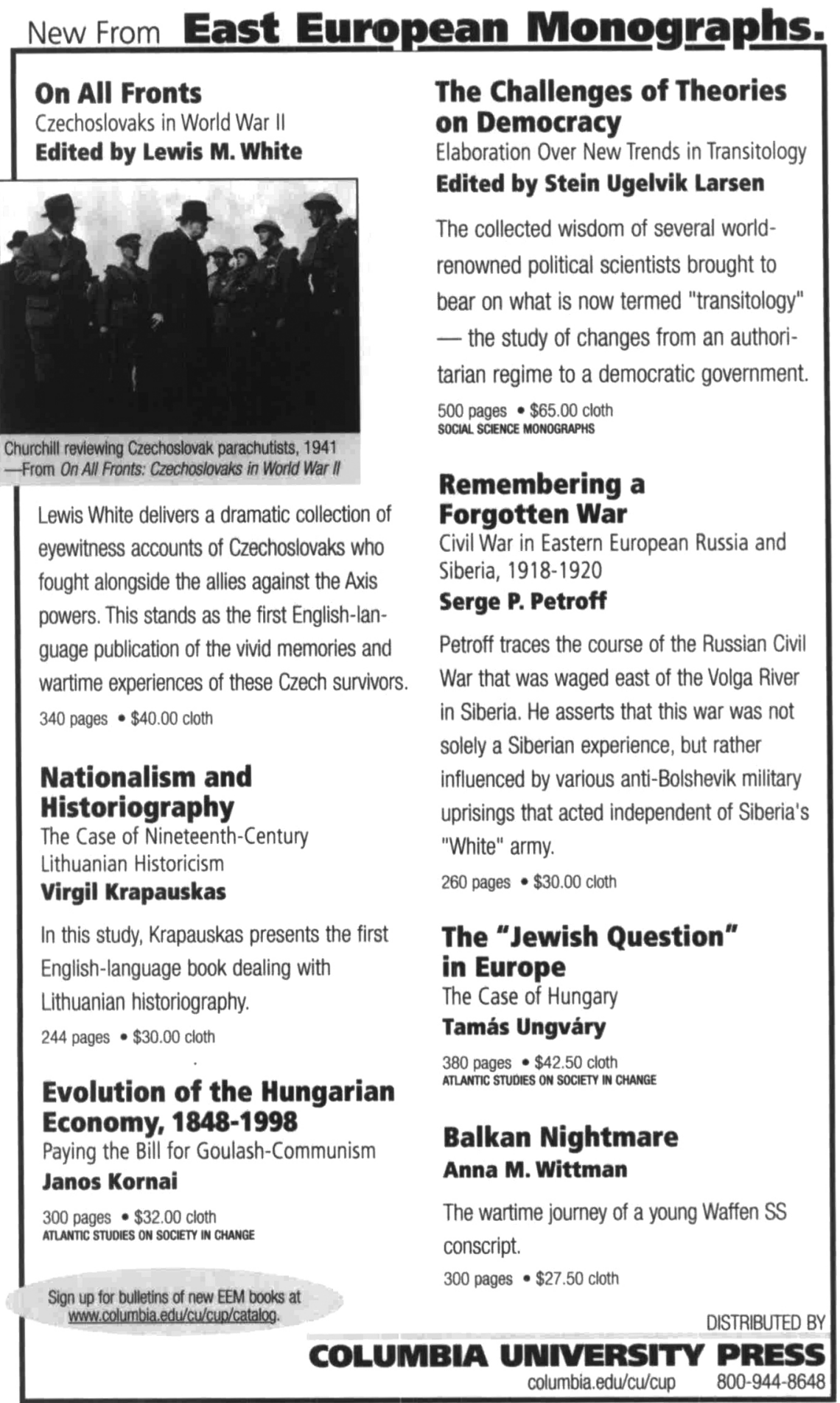


I N F OR M A T ION I N T E G R IT Y

incelligencly organized relevant pure accurate currenc balanced fair

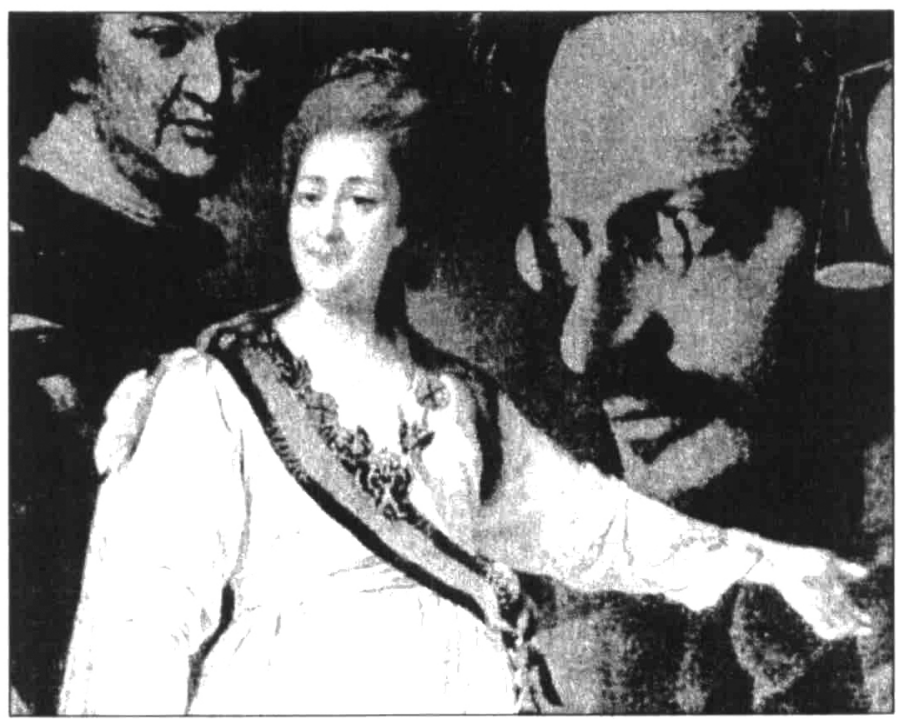

THE RUSSIAN ARCHIVES

Senior Editorial Advisor: Mark von Hagen, Pb.D. Columbia University

In an unprecedented arrangement, Primary Source Microfilm has been granted permission to microfilm collections from the largest and most closely guarded Russian archives. Their much-anticipated publication will allow researchers and students the opportunity to study an astounding historical record, that, until recently, has been largely inaccessible to scholars in the West.

Collections now available include:

- The Intercepted Correspondence of Russian Revolutionaries from the Special Department of the Police, 1906-1917- 175 reels

- Soviet Genetics - 188 reels

- The Military Papers of Leon Trotsky - 71 reels
FORTHCOMING

- Papers of the White Army: The Civil War, 1918-1921

- Institute of Economics of the Communist Academy, 1921-1937

- The Papers of Prince Gregory Potemkin

\section{LEGENDARY DISCOVERIES}

For detailed information, please call your Primary Source Microfilm representative at 1 (800) 444-0799 or send an e-mail to sales@galegroup.com. Outside the U.S. and Canada, please call +4402072572930 or send an e-mail to international@galegroup.com.

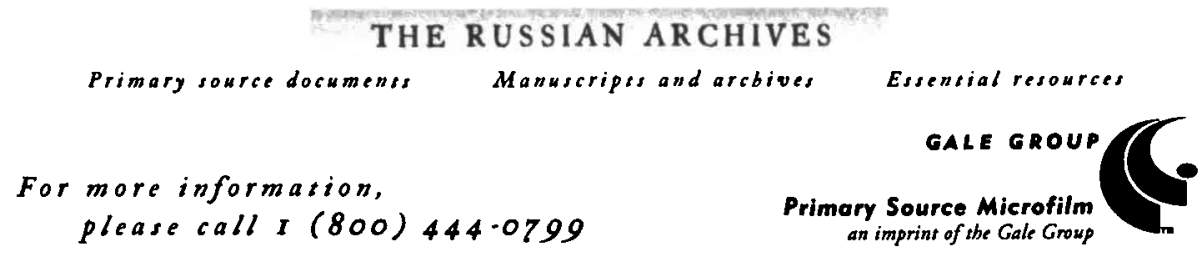




\section{Russianstudies}

Bolsheviks and the Bottle

Drink and Worker Culture in

St. Petersburg, 1900-1929

Laura L. Phillips

"An innovative and fascinating exploration of worker culture through the prism of drink."

-Christine Worobec, author of Peasant Russia

- Shedding fresh light on issues of change, class, and gender in revolutionary St. Petersburg, Phillips probes the tenacious resiliency of alcoholcentered culture in the face of state efforts at prohibition. Bolsheviks and the Bottle will appeal to readers interested in alcohol studies, gender issues, and Russia's working-class culture.

214 pages $0.87580-264-8 \$ 38.00$ cloth

\section{"Godless Communists"}

Atheism and Society in Soviet

Russia, 1917-1932

\section{William B. Husband}

"The best and most comprehensive treatment of its subject to date....Strongly recommended." -Choice

"Elegantly written...extraordinarily rich, complex, and far-reaching."

-Gregory Freeze, Brandeis University

- Examining Bolshevik efforts to create an atheistic state, Husband discovers how tightly religious belief was woven into the fabric of daily life in Russia.

241 pages $0-87580-257-5 \$ 36.00$ cloth

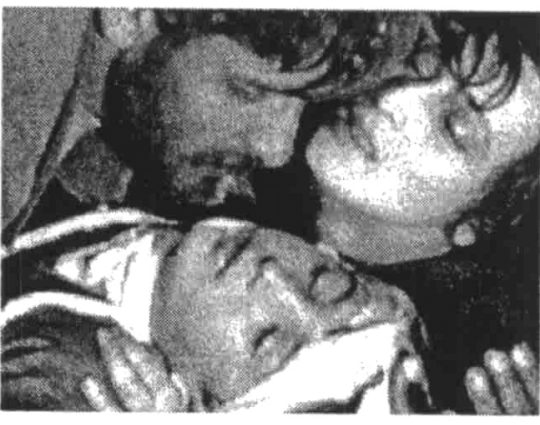

\section{The Enemy on Trial}

Early Soviet Courts on

Stage and Screen

Julie A. Cassiday

"Highly original and lucid."-Lynn Mally, University of California, Irvine

- In this provocative interdisciplinary study, Cassiday shows how Soviet show trials deliberately used avantgarde drama and cinema to educate the citizenry about the new social order. She examines how elements of theater and film were incorporated into Soviet courtrooms, turning public trials into vehicles for propaganda. Illustrated with evocative photographs and film stills, this book will engage readers interested in drama, film, and propaganda studies as well as Soviet culture.

280 pages, illus. $0-87580-266-4 \$ 38.00$ cloth

\section{im Northern Illinois} University Press

310 N. Fifth St., DeKalb Illinois 60115

815-753-1075 Fax 815-753-1845

www.niu.edu/univ_press 


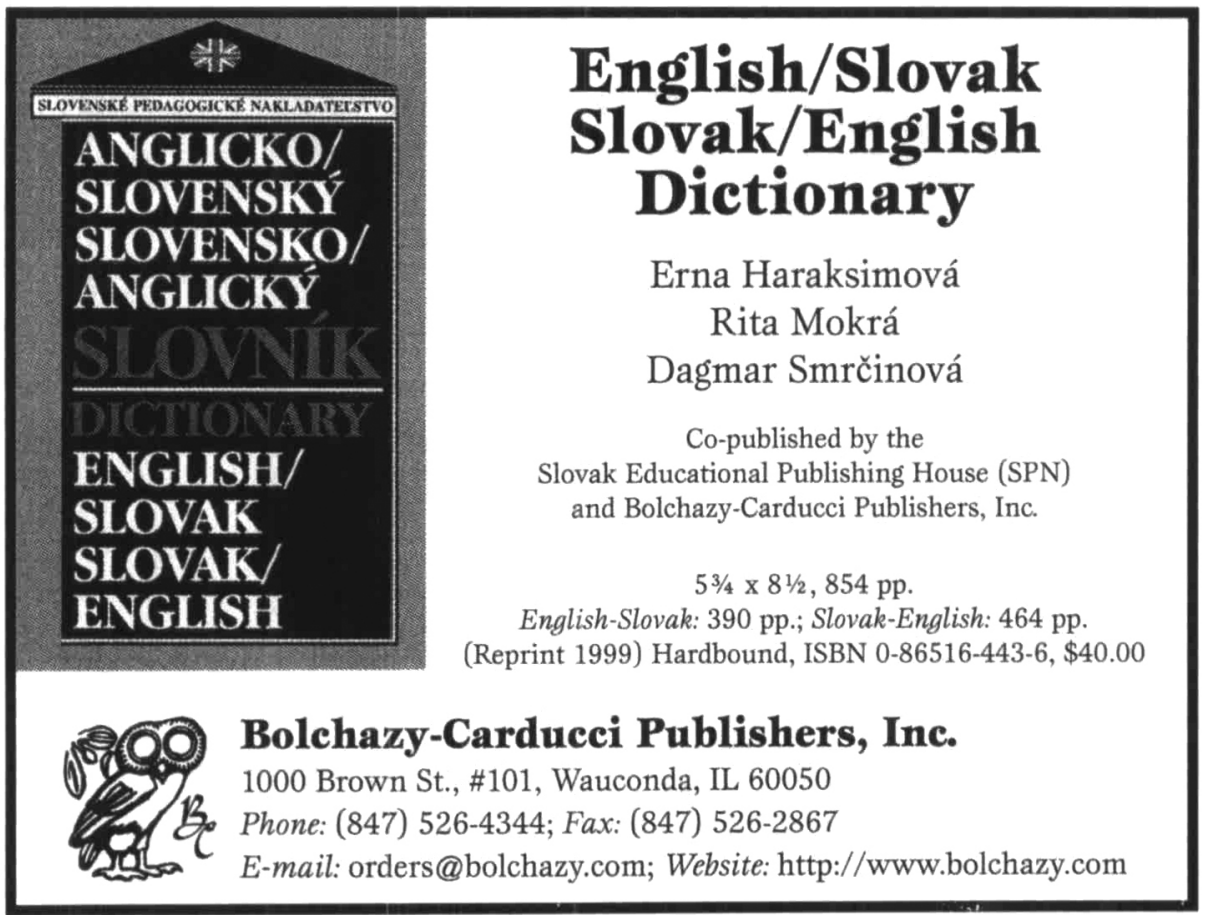

\section{Nationalism and Ethnicity Terminologies}

An Encyclopedic Dictionary and Research Guide

$$
\text { by Thomas Spira }
$$

Nationalism and Ethnicity Terminologies (NET) for the first time organizes the key terms used in the study of nationalism and ethnicity under one cover for researchers.

NET is based on definitions actually used by scholars in published research. Entries are of three general formats. Brief items cite one author and give easily understood definitions. Mini-essays cite several authors and give varied definitions. Longer essays cite numerous authors and address complex definitional issues. Numerous See also's serve as guides to cognate words, opposite meanings, concepts, related research terminologies. These appear at end of most entries.

7,000 entries, 3,000 bibliographic citations. Contents: A-B-C Paradox-Zollverein. Ixi, 758 pp. $7 \times 10$ in. Cloth. \$125. In print. ISBN 0-87569-205-2.

"[NET] is simply in a class of its own with no comparisons and is highly recommended"-American Reference Books Annual

Academic International Press

POB $1111 \mathrm{~N}$ - Gulf Breeze FL • 32562-1111 - USA

850-934-0953 (fax) • info@ai-press.com • www.ai-press.com 


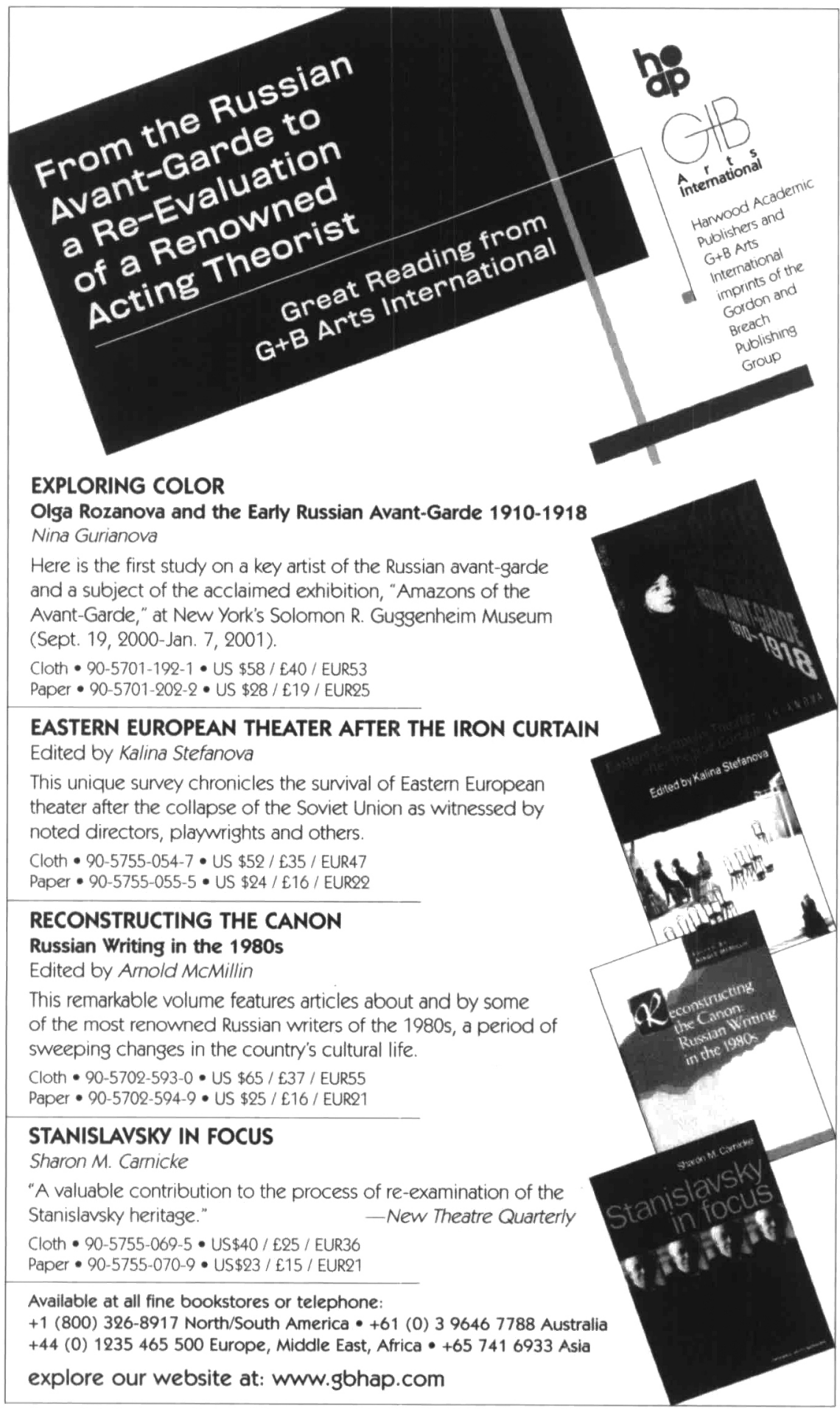




\section{Languages of Community}

The Jewish Experience in the Czech Lands

HILLEL J. KIEVAL

"An engaging and highly nuanced portrait of one of European Jewry's most interesting but least known communities... Kieval has a masterful command of a century and a half of Czech Jewish history." - David Sorkin, author of

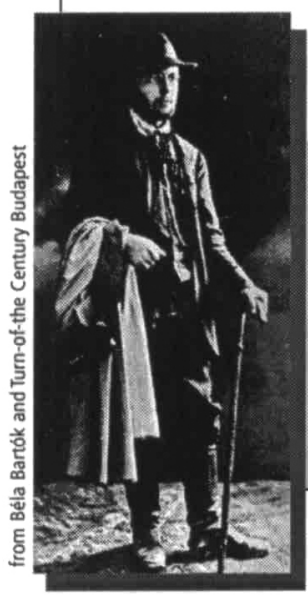

Moses Mendelssobn and the Religious Enlightenment

An S. Mark Taper Foundation Book in Jewish Studies

$\$ 45.00$ hardcover

Béla Bartók and Turn-of-the-Century Budapest JUDIT FRIGYESI

NEW IN PAPERBACK "An imaginative and powerful reinterpretation of Bartók's aesthetic achievement... presented as integrally related to its historical milieu."

-Mary Gluck, author of Georg Lukas and His Generation $\$ 19.95$ paperback

At bookstores or order (800) 822-6657 - www.ucpress.edu UNIVERSITY Of CALIFORNIA PRESS

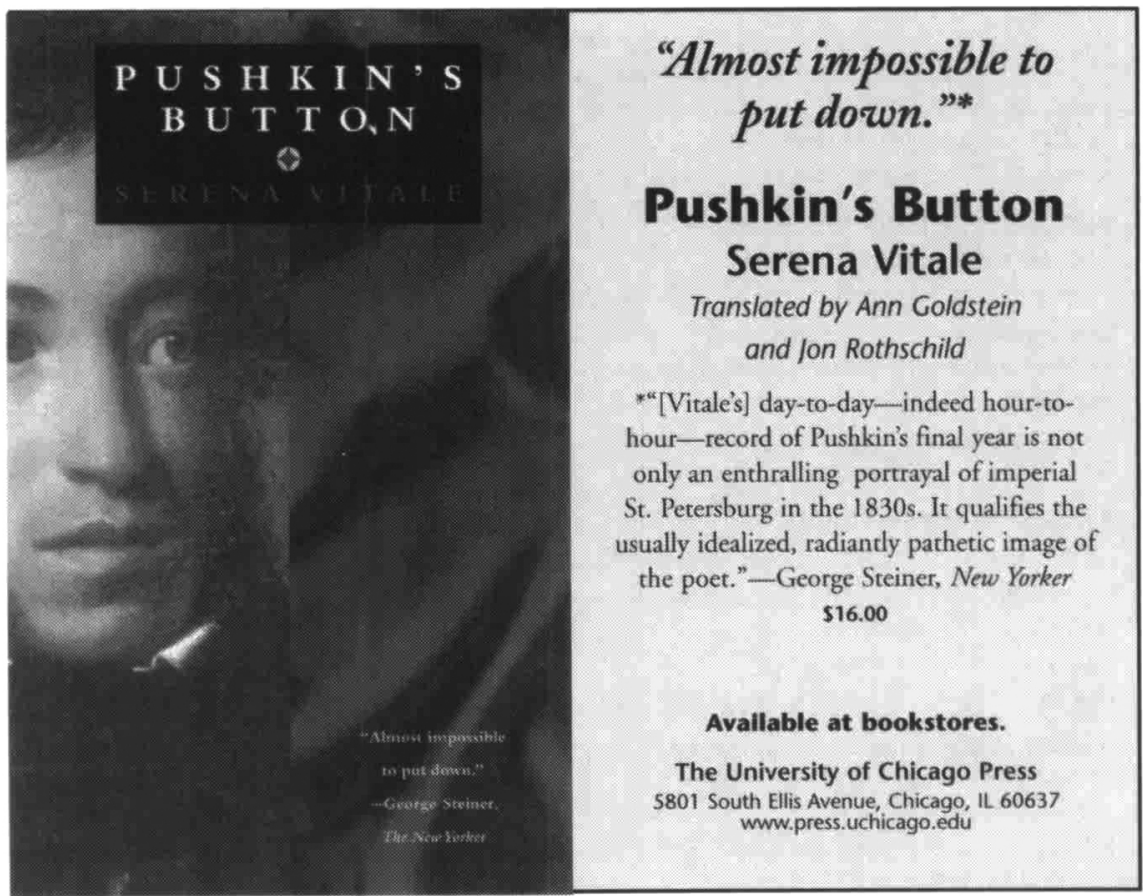




\section{Hammer and Rifle}

\section{The Militarization of the}

Soviet Union, 1926-1933

\section{David R. Stone}

"Based on prodigious research in newlyaccessible Russian archives, Stone's landmark book makes a significant contribution to our understanding of the advent of the Soviet garrison state. Touching on nearly every significant issue of the period, he deepens, challenges, or modifies many existing interpretations and cuts through the fog of conjecture, theory, and half-truths that still cloaks the era between 1926 and 1933."

-Bruce Menning, author of Bayonets before

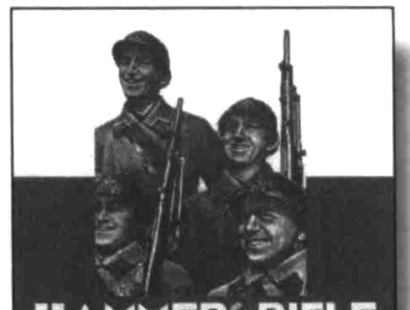

KAMMER ARIFLE

I. 117 iा! $1 \mathrm{k}$

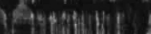
$=-\ln$ The Militarization of the Soviet Union, 1926.1933 DAVDR.STONE Bullets: The Imperial Russian Army, 1861-1914

"An important contribution to the field of Soviet military, economic, and political history."-Steven Miner, author of Between Churchill and Stalin and Stalin's Holy War

Selection of the History Book Club Modern War Studies, 304 pages, Cloth $\$ 39.95$

\section{The Battle of Kursk}

David M. Glantz and

Jonathan M. House

"The most detailed, authoritative, and thorough analysis of the massive battle that led to the final victory of the Red Army over the Germans. This outstanding book deserves the highest praise."-Malcolm Mackintosh, author of Juggernaut: A History of Soviet Armed Forces

Main Selection of the History Book Club Modern War Studies, 480 pages,

45 photographs, 32 maps, Cloth $\$ 34.95$

\section{Zhukov's Greatest Defeat}

\section{The Red Army's Epic Disaster in Operation Mars, 1942}

David M. Glantz

"Drawing upon recently declassified Russian archival materials, Glantz brings Operation Mars vividly to life." - New York Times Book Review

"Vividly powerful, compelling."

\section{-World War II}

Main Selection of the History Book Club Modern War Studies, 432 pages,

24 photographs, 24 maps, Cloth $\$ 39.95$ 


\section{LIBRARIES UNLIMITED}

- NEW -

\section{INDEPENDENT UKRAINE}

A Bibliographic Guide to English-Language Publications, 1989-1999

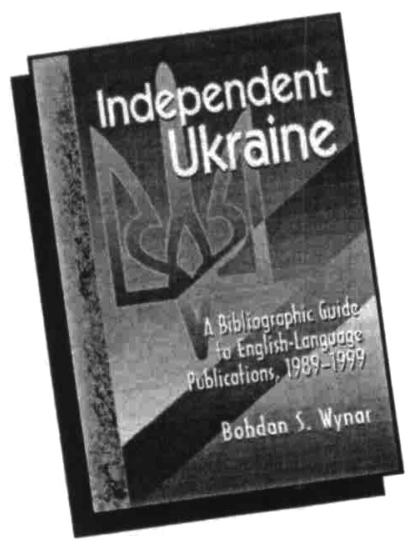

Review of the previous edition:

"The bibliography is in a real sense an intelligent guide to Ukrainian studies. The structuring of the work is a model for other bibliographers."

-Slavic Review

\section{Also Available}

- Ukraine: A Bibliographic

Guide to English-Language

Publications

Bohdan S. Wynar

0-87287-761-2 \$65.00 Retail

- Ukrainian Nationalism

3d Edition

John A. Armstrong

0-87287-755-8 \$45.00 Retail

\section{Bohdan S. Wynar}

Scholarly works and research regarding all things Ukrainian have increased dramatically during the nation's first decade of independence, and so too has the need for a guide to the ever-growing volume of publications. This work responds with approximately 1,700 evaluative annotations describing key books, articles, scholarly essays, and doctoral dissertations published about Ukraine in the past decade.

This volume complements and supplements Wynar's previous work, Ukraine: $A$ Bibliographic Guide to English-Language Publications, published in 1990. Together the two books provide a standard of bibliographic control and a comprehensive overview of the intellectual activity in the field.

2000 xiv, 552p. $7 \times 10$ cloth ISBN 1-56308-670-0\$85.00 Retail

Libraries Unlimited • Dept. A251 • P.O. Box 6633 • Englewood, CO 80155 • U.S.A. 800-237-6124 • www.lu.com • lu-books@lu.com 


\section{COMING OF AgE IN POST-SOVIET RUSSIA}

\section{FRAN MARKOWITZ}

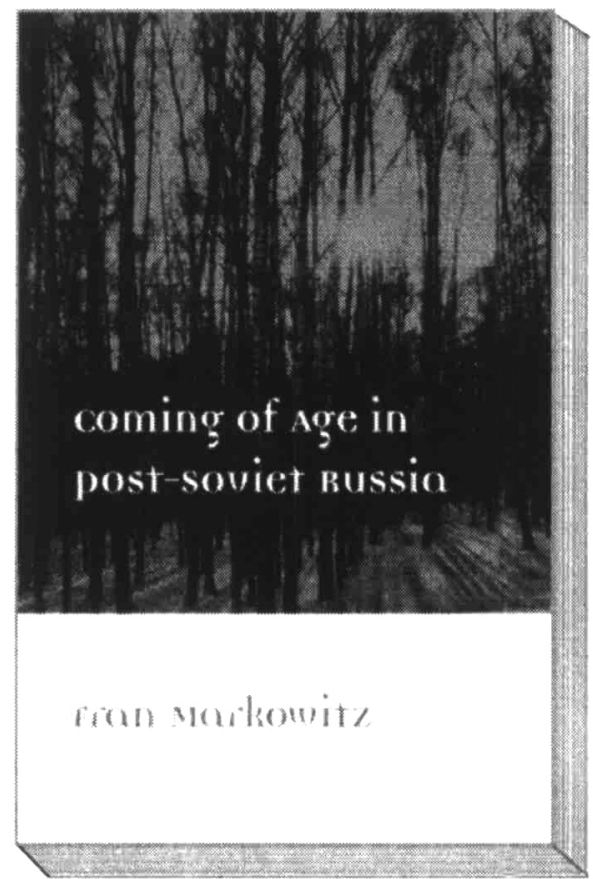

Illustrated with photographs

Cloth, $\$ 45.00$

Paper, $\$ 18.95$
"A beautifully written portrait of post-Soviet life that provokes new thinking about the stabilities of the very concepts of culture, nation and the person." - Bruce Grant, author of In the Soviet House of Culture: A Century of Perestroikas

"Compassionate, critically engaged, and eminently readable. . . . Hints provocatively at ways Russian society might be re-shaped by its younger generations, while giving us a poignant sense of the immense challenges Russia's young people face." - Nancy Ries, author of Russian Talk: Culture and Conversation during Perestroika 


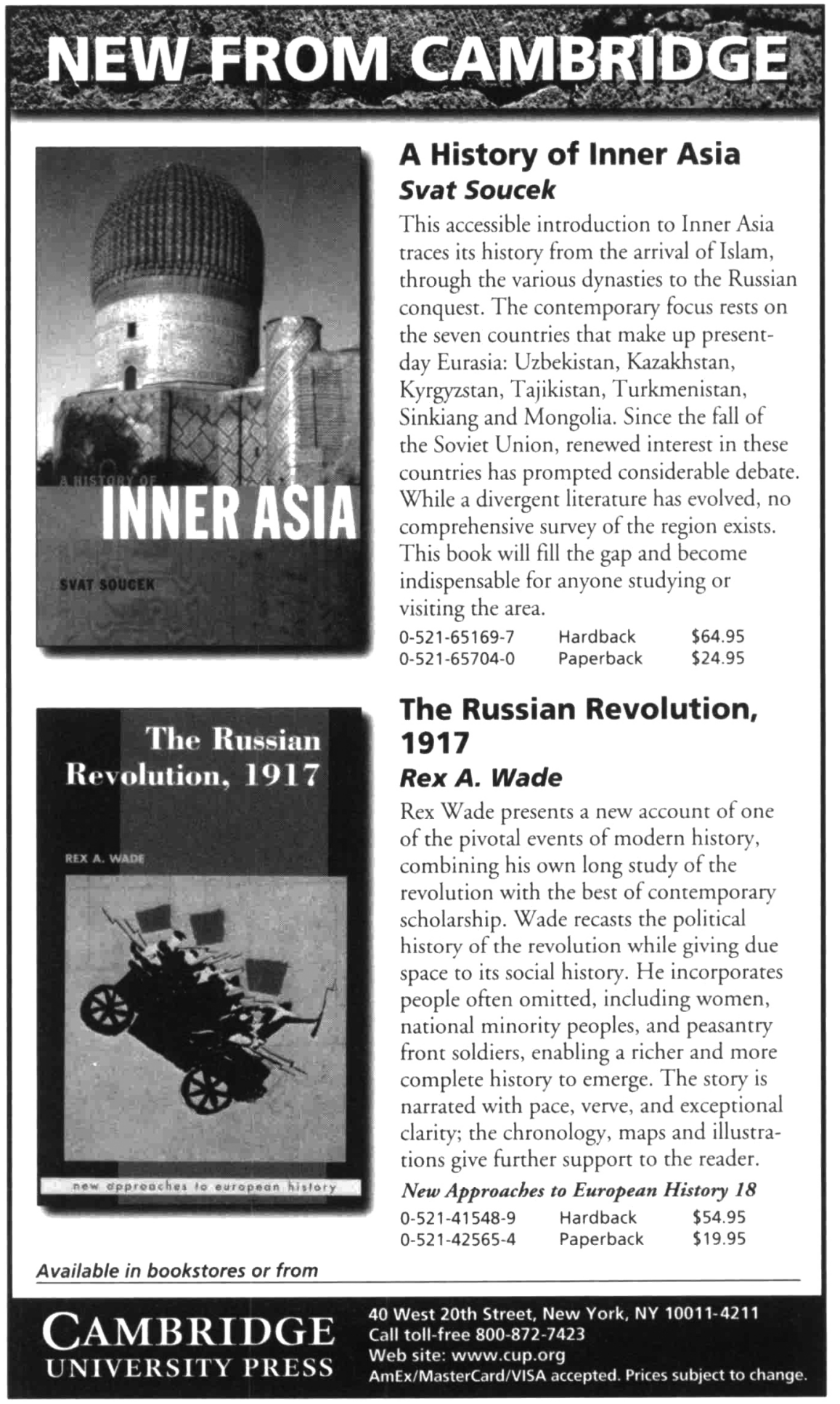

